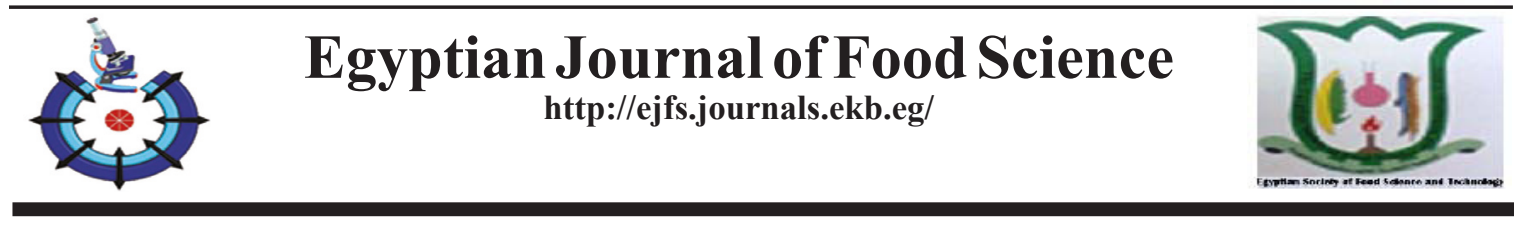

\title{
Production and Evaluation of Stirred Synbiotic Fermented Milk Fortified with Fig Fruit (Ficus carica L.)
}

\author{
Samah A. Abd-Eltawab ${ }^{1^{*}}$ Warda M. A. Ebid ${ }^{2}$ \\ ${ }^{1}$ Food Science and Technology Department, Faculty of Agriculture, Fayoum \\ University, Fayoum, Egypt \\ ${ }^{2}$ Dairy Department, Faculty of Agriculture, Fayoum University, Fayoum, Egypt
}

\begin{abstract}
$\mathbf{T}$ HE OBJECTIVE of this study was to produce stirred probiotic fermented milk fortified with fig (Ficus carica L.) to be a source of milk ingredients like milk protein, calcium, magnesium, vitamin B12 and probiotic bacteria. In addition to rich fruit ingredients such as dietary fiber, polyphenols, antioxidants and different minerals. Therefore, figs puree was added to the milk (5, 10 and 20\% ) and the results obtained showed that, samples of T3 (with $20 \%$ fig puree) have the highest values for dietary fiber and polyphenols, which were $(0.61 \mathrm{~g}$ and 35.85 mg GAE/100g) respectively. Also, these samples have the highest percentage of antioxidants, as they have the lowest value of $\mathrm{IC}_{50}(13.89 \mathrm{mg} / \mathrm{ml})$ and highest value antiradical power (ARP) (0.0719). Samples of T3 have the highest contents of $\mathrm{K}, \mathrm{Mg}, \mathrm{Fe}, \mathrm{Ca}$ and $\mathrm{P}$ and their levels were $150.65,15.37,1.13,248.75$ and $136.95 \mathrm{mg} / 100 \mathrm{~g}$, respectively. The addition of fig puree in different concentrations in fermented milk affected the growth kinetics of $L$. acidophilus, where led to a decrease in $\mathrm{pH}$ and an increase in titratable acidity, because of the increase activity of L. acidophilus, as fig is an excellent substrate for the growth of them. The maximum counts of L. acidophilus at fresh and after 15 days of storage at $4 \pm 1{ }^{\circ} \mathrm{C}$ were 11.43 and 10.74 $\log \mathrm{cfu} / \mathrm{ml}$ for samples T3. Sensory evaluation showed that fig-fortified samples (T1, T2 and T3) were sensually acceptable compared to the control samples.
\end{abstract}

Keywords : Synbiotic, Fig fruit, Antioxidant, Total phenolic content.

\section{Introduction}

Yoghurt is world wide-spread fermented milk (Tamime and Robisons, 2007). It is commonly produced by the fermentation of Lactobacillus delbrueckii ssp., bulgaricusand Streptococcus thermophilus (O’Connell and Fox, 2001). Furthermore, yoghurt acts as a natural source of probiotics, that enhance the health via improving the digestion and absorption processes, as well as promoting food safety in human nutrition (Sanders, 2007). Probiotics, prebiotics and synbioticsupported foods are considered functional foods. In despite of that dairy products (including plain yoghurt) have a high nutritive value, they are poor sources for phenolic compounds, antioxidants and fibers (O'Connell and Fox, 2001), because the cattle milk has low values of phenolic compounds (about $49 \mathrm{mg}$ GAE/L) and fiber (Velazquez Vasquez et al., 2015). In order to increase the antioxidant properties and fiber contents of the dairy products, vegetables or fruits are added to meet consumer demands to produce what is called 'clean label' (Granato et al., 2017). Furthermore, DelloStaffolo et al. (2017) and Tomic et al. (2017) observed that probiotic activities increased in yoghurt fortified with dietary fibers. Fig (Fiscus carica) is a rich source of sugars, organic acids, minerals (such as manganese, copper, magnesium, calcium, and potassium), vitamins (such as vitamin $\mathrm{K}$ and $\beta$ - carotenes), polyphenols, flavonoids, fiber, as well as other

"Corresponding author : saa06@fayoum.edu.eg

Received :24/10/2019; accepted : 28/11/2019

DOI: 10.21608/EJFS.2019.18646.1026

(C)2019 National Information and Documentation Centre (NIDOC) 
compounds (such as arabinose, glycosides, $\beta$ amyrins, $\beta$ - setosterols and xanthotoxol) that showed beneficial properties(Jeong et al., 2009 and Vinson, 1999). In this context, our study is aimed to increase the nutritive values of the plain yoghurt by addition of fig in order to increase the phenolic compounds, antioxidants, minerals and fiber contents to meet human requirements. Consequently, addition of fig may increase the probiotic activity of the yoghurt for using it in human nutrition and medicine to reduce and treat obesity, hyper-cholesterolemia, hyper-lipemia, hypertension, gastrointestinal disorders, and promote gut microflora growth.

\section{Materials and Methods}

\section{Materials}

Milk, figs and sugar

Fresh buffaloes' milk was obtained from the production farm, Fac. of Agric., Fayoum Univ. Fig fruit (Ficus carica L.) and sugar were obtained from local market in Fayoum province. Bacterial strains Lactobacillus acidophilus (type La 5) was obtained from Chr. Hansen's laboratories, Copenhagen, Denmark.

\section{Methods}

\section{Preparation of fig puree}

The whole ripe figs were, washed with tap water and blended into paste using a blender then the paste was heated to $100^{\circ} \mathrm{C}$ for $10 \mathrm{~min}$, and the fruit purees were cooled to $45^{\circ} \mathrm{C}$ and stored cool until used.

\section{Manufacture of synbiotic fermented milk}

Stirred synbiotic fermented milk was manufactured according to (Lee and Lucey 2010) with some modification as follow :

1. Milk was filtered with a clean sterile cheesecloth to sieve from debris and foreign materials.

2. Sugar was added as a sweetener $(6 \% \mathrm{w} / \mathrm{v})$.

3. The mixture was heated $90^{\circ} \mathrm{C}$ for $15 \mathrm{~min}$ followed by cooling rapidly in iced water to $45^{\circ} \mathrm{C}$.

4. The fig purees were added to get three different concentrations $[5 \% \mathrm{w} / \mathrm{w}(\mathrm{T} 1), 10 \% \mathrm{w} / \mathrm{w}(\mathrm{T} 2)$ and $20 \% \mathrm{w} / \mathrm{w}$ (T3)], in addition to the control (C) without fig puree.

5. All treatment was inoculated with $2 \%(\mathrm{v} / \mathrm{v})$ of Lactobacillus acidophilus.

6. All treatments were Incubate at $42^{\circ} \mathrm{C}$ until complete coagulation.

7. After complete coagulation, the cooling curd is stirred to break by blender (Stirred synbiotic fermented milk).
Stirred synbiotic fermented milk samples were stored at $4 \pm 1{ }^{\circ} \mathrm{C}$ for 15 days during that period, sensory, physicochemical and microbiological evaluation were carried out at fresh (0), 5, 10 and 15 day intervals.

\section{Physicochemical analysis}

Moisture, protein, fat, ash content and $\mathrm{pH}$ value were determined according to the method described by AOAC (2012).

\section{Total phenolic content analysis}

Total phenolic contents of Stirred synbiotic fermented milk were measured by Folin-Ciocalteu method according to Singleton and Rossi (1965). Using gallic acid as a standard,Folin-Ciocalteu (FC) reagent was diluted with pure water $(1: 10)$ to prepare working solution. Sample or standard (1 $\mathrm{mL}$ ) was mixed with $\mathrm{FC}$ working solution $(5 \mathrm{~mL})$ and incubated for $3 \mathrm{~min}$, and then $4 \mathrm{~mL}$ of sodium carbonate $(75 \mathrm{~g} / \mathrm{L})$ was added into this mixture. After incubation for 2 hours at room temperature in dark, the samples were centrifuged for $2 \mathrm{~min}$ at 12.000 RPM. Absorbance values of samples were measured at $760 \mathrm{~nm}$ against to distilled water by using a spectrophotometer. Results were expressed as gallic acid equivalents (GAE) per $100 \mathrm{~g}$ of yogurt samples.

\section{Determination of antioxidant activity}

Antioxidant capacity of yogurt samples were determined by radical scavenging ability using stable DPPH (2,2-azinobis 3 ethylbenzothiazoline-6-sulfonic acid) as described by (Akowuah et al. 2005) using samples of concentration $(5,10,15,20$ and $25 \mu \mathrm{g} / \mathrm{mL})$. The percent inhibition of the tested samples was evaluated by comparison with a control. Each sample was measured in triplicate, and an average value was calculated. Antioxidant activity was expressed as a percentage of inhibition compared to control as follows: $\%$ inhibition $=\left[\left(\mathrm{A}_{\text {control }}-\mathrm{A}_{\text {sample }}\right) / \mathrm{A}_{\text {control }}\right] \times 100$ Where $A$ is the absorbance at $515 \mathrm{~nm}$ in DPPH method. Antioxidant activity $\left(\mathrm{IC}_{50}\right)$ and the antiradical power (ARP) were calculated and the method explained by Brand-Williams et al., (1995).

\section{Minerals analysis}

\section{Sample preparation}

Samples were ground and approximately 0.2 $-0.3 \mathrm{~g}$ of sample was weighed and added into the polytetrafluoroethylene digestion vessel with $5 \mathrm{~mL}$ of concentrated $\mathrm{HNO}_{3}$ and $2 \mathrm{~mL}$ of hydrogen peroxide $\left(\mathrm{H}_{2} \mathrm{O}_{2}\right)$. Subsequently, the samples were

Egypt. J. Food. 47, No.2 (2019) 
digested using a two-step temperature program. After digestion and cooling, each solution was evaporated to $\sim 2 \mathrm{~mL}$ and diluted with deionized water in a $50-\mathrm{mL}$ volumetric flask for theAtomic Absorption Spectroscopy(AAS) analysis. The results were reported as the average of three repeated measurements, and all digestions were conducted in triplicate.

An Agilent atomic absorption spectrometer equipped with Agilent single-element hollow cathode lamps and a 10-cm air-acetylene burner was used for the determination of the metal ions.

\section{Microbiological analysis}

Total mold and yeast, coliform bacteria group count and Staphylococcus aureus Lactic acid bacteria (LAB) were determined according to the method described by APHA (1992).

\section{Sensory evaluation}

The appearance, flavor, color and consistency were evaluated of each stirred synbiotic fermented milk samples on a four-point hedonic scale in which $1=$ extremely dislike and $4=$ extremely like according to (Helmyatiet al., 2015) intervals storage period: fresh, 5, 10 and 15 days. Sensory evaluation was carried out by a panel consisting 10 panelists of staff members of Dairy Science and Food Science and Technology Departments, Faculty of Agriculture, Fayoum University.

\section{Statistical analysis}

Results are expressed as means of at least three replicates. All obtained data were subjected to the statistical analysis using General Linear Models (GLM) were performed using SPSS (1999) for windows, version 19 software packages. Significant differences among treatments, storage period and the interaction means between them were compared at $\mathrm{P} \leq 0.005$ level of significance using Duncan's multiple range test(Duncan, 1955).

\section{Results and Discussions}

Proximate composition

The contents of moisture, protein, fat and ash determined in stirred fermented milk fortified with different concentration of fig are shown in Table 1. The moisture content was ranged from 79.48 to $80.88 \%$, the highest values were observed in samples of $\mathrm{T}_{3}$, This may be due to the high concentration of fig puree as the moisture content of fig pureewas $85 \%$.

The percentage of protein and fat contents of all samples were decreased from 4.14 and $6.13 \%$, respectively, in control samples to 3.33 and $5.25 \%$ in samples of $\mathrm{T} 3$ respectively, these can be attributed to the high moisture content and very low protein and fat contents $(0.88$ and $0 \%$ respectively) in fig puree containing samples.

Concerning the percentage of ash contents in the examined samples as shown in Table 1 . The highest percent of ash was $2 \%$ in samples of T3, followed by samples of T2 and T1 (1.77\% and $1.68 \%$ ) respectively, while the ash percentage of the control samples was the lowest $(1.53 \%)$. Furthermore, the high ash contents in stirred fermented milk samples fortified with fig puree were directly related to the fig concentrations used. The ash percentage in fig-fortified milk samples were significantly higher $(\mathrm{P} \leq 0.05)$ than that recorded in control samples (without fig). These results in indicating that adding of fig to milk will increase its ash content as the fig ash content is high (about $4.65 \%$, Neha et al., 2014) because the high mineral contents in the fig (Ali et al., 2002).

TABLE 1. Physicochemical composition of Stirred synbiotic fermented milk fortified with fig puree.

\begin{tabular}{|c|c|c|c|c|c|}
\hline Treatments & Moisture & Protein & Fat & Ash & Dietary fiber \\
\hline $\mathbf{C}$ & $79.48^{\mathrm{d}} \pm .020$ & $4.14^{\mathrm{a}} \pm 0.025$ & $6.13^{\mathrm{a}} \pm 0.06$ & $1.53^{\mathrm{d}} \pm 0.015$ & $0.04^{\mathrm{d}} \pm 0.01$ \\
\hline $\mathbf{T}_{1}$ & $79.76^{c} \pm 0.047$ & $4.07^{b} \pm 0.023$ & $5.93^{b} \pm 0.025$ & $1.68^{\mathrm{c}} \pm 0.030$ & $0.43^{\mathrm{c}} \pm 0.01$ \\
\hline $\mathbf{T}_{2}$ & $80.39^{b} \pm 0.045$ & $3.67^{\mathrm{c}} \pm 0.051$ & $5.62^{\mathrm{c}} \pm 0.060$ & $1.77^{\mathrm{b}} \pm 0.015$ & $0.50^{b} \pm 0.10$ \\
\hline Fig puree & $85 \pm 0.020$ & $0.88 \pm 0.01$ & $0 \pm 0$ & $1.0 \pm 0.11$ & $2.1 \pm 0.10$ \\
\hline
\end{tabular}

C: Stirred fermented milk control without fig; $-\mathrm{T}_{1}$ : Stirred fermented milk with $5 \%$ fig;

$\mathrm{T}_{2}$ : Stirred fermented milk with $10 \%$ fig; $-\mathrm{T}_{3}$ : Stirred fermented milk with $20 \%$ fig.

Values with different superscript letters in a column are significantly different $(\mathrm{P} \square 0.05)$. 
The effects of different concentration of fig puree on the dietary fiber content of stirred fermented milk are shown in Table 1. The values of dietary fiber content were increased by increasing the concentration of fig puree in samples, which may be due to the high percent $(3.68 \%)$ of dietary fiber in fig (Soni, et al. 2014). Values of fiber content were $0.04,0.43,0.50$ and $0.61 \mathrm{~g}$ dietary fiber $/ 100 \mathrm{~g}$ in stirred fermented milk samples prepared with $0,5,10$ and $20 \%$ of puree fig respectively. So we could be assumed that adding of fig puree to milk for producing stirred fig-fortified fermented milk will enhance its fiber content. The obtained results may be, more or less coincides with that results obtained by Hanan, 2018; who found that the dietary fiber content was increased by using date powder in yoghurt samples, and the results of Sendra, et al., 2010 who found that yoghurt fortified with different types of fruits could increase the fiber content and consequently yoghurt samples were stable during storage in physicochemical and rheological properties.

The effect of adding fig puree with different concentration to stirred fermented milk on minerals contents as shown in Table 2. By increasing the concentration of fig puree, the concentrations of minerals in samples increased. Samples of $\mathrm{T}_{3}$ have the highest contents of $\mathrm{K}, \mathrm{Mg}$, $\mathrm{Fe}, \mathrm{Ca}$ and $\mathrm{P}$ and their levels were $150.65,15.37$, $1.13,248.75$ and $136.95 \mathrm{mg} / 100 \mathrm{~g}$, respectively, and these are followed by the concentration of minerals samples $\mathrm{T}_{2}$ and then the concentrations of minerals in samples $T_{1}$. The results in the present study are consistent with the previous observations of Soni, et al (2014) who demonstrated that dried fig fruit is an excellent source for minerals like $\mathrm{Ca}, \mathrm{Mg}, \mathrm{P}$ and $\mathrm{Fe}$, as these elements were present in the concentrations of $1545.46,679.04,365.75$ and $29.49 \mathrm{ppm}$,respectively. Furthermore, our results are parallel with the results of (McCance et Widdowson, 1993) who stated that adding fruits such as strawberries, raspberries and wild blackberries to yogurt increases the contents of the minerals. The lowest content of elements was obtained in the control samples (without adding fig) as the contents of minerals were 32.35, $13.82,0.39,195$ and $99.04 \mathrm{mg} / 100 \mathrm{~g}$ for $\mathrm{K}, \mathrm{Mg}$, $\mathrm{Fe}, \mathrm{Ca}$ and $\mathrm{P}$, respectively. These results are, to some extent, in agreement with the data obtained by Hayat and Salem (2011) who demonstrated that the minerals content in Yoghurt nature were $54.05,13.22,0.53$ and $195.04 \mathrm{mg} / 100 \mathrm{~g}$ for $\mathrm{K}$, $\mathrm{Mg}, \mathrm{Fe}$ and $\mathrm{Ca}$, respectively. These results are lower than those recorded by Zamberlinet al (2012) who observed that the average content of $\mathrm{K}, \mathrm{Mg}, \mathrm{Ca}$ and $\mathrm{P}$ in yogurt was $280,19,200$ and $170 \mathrm{mg} / 100 \mathrm{~g}$, respectively. Finally we can say that adding of fig puree to fermented milk will increase the concentrations of $\mathrm{K}, \mathrm{Mg}, \mathrm{Fe}, \mathrm{Ca}$ and $\mathrm{P}$ in it and consequently increasing its nutritive value. Furthermore these results are supported by the results of ash.

\section{Total phenolic content}

Polyphenols have a significant role as antioxidant stronger than vitamins $\mathrm{C}$ and $\mathrm{E}$, as they work by their ideal structure to bind free radical and prevent their harmful oxidative effect (Rice-Evans, 1997). The effect of adding fig puree to stirred fermented milk on its content of total phenolic compounds (TPC) is shown in Table (3). By increasing the concentration of fig puree added to stirred fermented milk, the levels of TPC increase. The highest value of TPC was $35.85 \mathrm{mg} \mathrm{GAE} / 100 \mathrm{~g}$ of wet matter for samples $\mathrm{T}_{3}$. Which are followed by the values of $\mathrm{T}_{2}(20.86 \mathrm{mg}$ $\mathrm{GAE} / 100 \mathrm{~g}$ of wet matter) then followed by the levels of $\mathrm{T}_{1}(9.4385 \mathrm{mg} \mathrm{GAE} / 100 \mathrm{~g}$ of wet matter). The minimum value was $3.9485 \mathrm{mg}$ GAE/100g of wet matter for control sample. Such finding coincides with that obtained by Raikos et al. (2019) who found that the level of TPC of control yoghurt ranged from 45 to $70 \mathrm{ug} \mathrm{GAE} / \mathrm{ml}$. These results are much higher than those obtained by Shabboo and Ahmad (2015), who demonstrated that the TPC in plain yogurt was $4.8 \mathrm{ug}$ GAE/ml.These differences may be due to many properties like the geographical origin, varieties, extraction conditions, and postharvest storage conditions (Soufi et al., 2014).

TABLE 2. Minerals content in stirred synbiotic fermented milk fortified with different ratios of fig puree.

\begin{tabular}{cccccc}
\hline \multirow{2}{*}{ Samples } & $\mathbf{K}$ & $\mathbf{M g}$ & $\mathbf{F e}$ & $\mathbf{C a}$ & $\mathbf{P}$ \\
\cline { 2 - 6 } & 32.35 & 13.82 & 0.39 & 195 & 99.04 \\
$\mathrm{C}$. & 39.94 & 14.18 & 0.63 & 209.26 & 107.92 \\
$\mathrm{~T}_{1}$ & 43.27 & 14.6 & 0.98 & 225.74 & 121.9 \\
$\mathrm{~T}_{2}$ & 50.65 & 15.37 & 1.13 & 248.75 & 136.95 \\
$\mathrm{~T}_{3}$ &
\end{tabular}

C: Stirred fermented milk control without fig; $\mathrm{T}_{1}$ : Stirred fermented milk with $5 \%$ fig; $\mathrm{T}_{2}$ : Stirred fermented milk with $10 \%$ fig; $\mathrm{T}_{3}$ : Stirred fermented milk with $20 \%$ fig.

Egypt. J. Food. 47, No.2 (2019) 
The increase in TPC in stirred fermented milkwith the addition of fig puree is due to the fact that figs are considered good sources of phenolic compounds and antioxidants. As the value of TPC in fig puree was $195.28 \mathrm{mg}$ $\mathrm{GAE} / 100 \mathrm{~g}$ of wet matter basis. These results are slightly lower than those recorded by Mostapha and Hayette(2015) who denoted that the varieties of fig with a dark skin contain higher amounts of total phenolic, anthocyanins, total flavonoids, proanthocyanidins and flavonols than the lighter varieties, the average values of TPC were 618.85 and $514.72 \mathrm{mg} / 100 \mathrm{~g}$ of dry matter for the dark and light dried fig (Ficus carica L.) respectively. Furthermore, Vijaya Kumar Reddy et al. (2010) and Capanoglu (2014) who noticed that the TPC in Indian and Turkish dried fig were 331.93 and $169.4 \mathrm{mg} \mathrm{GAE} / 100 \mathrm{~g}$ of wet matter, respectively. These differences may be due to the diversity of the geographical origin, extraction conditions, varieties and postharvest storage conditions (Bachirbey, 2013).

\section{Antioxidant activity}

There are many fruits rich in phenolic compound, which are added to dairy products to support them with antioxidants capacity such as fig puree. Table 4 revealed that the antioxidant activity of stirred fermented milk fortified with different concentration of fig puree was up to ten times as high as that of the stirred fermented milk without adding fig puree. $\mathrm{T}_{3}$ samples, which have the highest percentage of antioxidants, as they have the lower value than $\mathrm{IC}_{50}(13.89 \mathrm{mg} /$ $\mathrm{ml}$ ), followed by samples $T_{2}$ and $T_{1}$, as values of $\mathrm{IC}_{50}$ were 19.58 and $24.45 \mathrm{mg} / \mathrm{ml}$, respectively. Our results are agreement with results obtained by Soni, et al., 2014 who found that the antioxidant activity $\left(\mathrm{IC}_{50}\right.$ value) of dried fig extract determined against ascorbic acid was $19.8 \mathrm{mg} / \mathrm{ml}$ in the extract that is considered to be very good. On the other hand, control sample has the lowest percentage of antioxidants, which have the highest value of $\mathrm{IC}_{50}$ and value was $237.79 \mathrm{mg} / \mathrm{ml}$. The values of ARP are in contrast with those of $\mathrm{IC}_{50}$, as the higher the $\mathrm{IC}_{50}$ the lower the $\mathrm{ARP}$ and vice versa because high ARP values indicate that high efficiency as antioxidants.
Changes of stirred fermented milk during refrigerated storage

The changes of $\mathrm{pH}$ value in stirred fermented milk samples during storage period at $4 \pm 1{ }^{\circ} \mathrm{C}$ was affected by the addition of fig puree are shown in Table 5. The higher amount of fig added, the lower the values of $\mathrm{pH}$ during storage period. The maximum values of $\mathrm{pH}$ were recorded in fresh and after 15 days of storage for control samples, the values were 5.34 and 4.64 respectively, while samples $\mathrm{T}_{3}$ (with the highest percentage of fig 20\%) had the lowest value of $\mathrm{pH} 4.77$ and 4.24 at fresh and after the end of storage period, respectively .Similar results were obtained by Erman et al., (2011),Samah et al., (2014) andAshwani and Dinesh (2015). The $\mathrm{pH}$ values of the control samples are significantly higher ( $\mathrm{P}$ $\leq 0.05$ ) than those of fig-fortified fermented milk samples (T3, T2 and T1) over the storage periods. Also, same trend is recorded in treatment means of the samples throughout the storage period.

The results in Table 6 Showed that the changes of titratable acidity in stirred fermented milk samples during storage period at $4 \pm 1$ ${ }^{\circ} \mathrm{C}$. The titratable acidity values of the figfortified fermented milk samples (T1, T2 and T3 respectively) were significantly $(\mathrm{P} \leq 0.05)$ higher than that of control samples over the storage periods. The same trends were observed in the results of treatment means and results of period means throughout storage period at $4 \pm 1$ ${ }^{\circ} \mathrm{C}$. The acidity in samples $\mathrm{T}_{3}$ was significantly higher than those of control and other treatments samples in fresh and throughout the storage period. The maximum value of acidity after 15 days of storage at $4 \pm 1{ }^{\circ} \mathrm{C}$ was $0.91 \%$ recorded in samples $\mathrm{T}_{3}$, which is followed by values of 0.80 , 0.72 and $0.68 \%$ recorded in samples of $\mathrm{T}_{2}, \mathrm{~T}_{1}$ and control, respectively, over the time of storage at $4 \pm 1{ }^{\circ} \mathrm{C}$. These results, to some extent, agree with the data obtained by Celik and Sat (2006), Bakirci and Kavaz (2008) and Samah et al. (2014) who demonstrated that titratable acidity increased during storage for fruit-flavoured yogurts might be due to the acidity of fruit. The increase in the titratable acidity may be due to the acidity which is resulted from the conversion of lactose to lactic acid during the storage period (Hossain et al., 2012). This can be also explained in the light of the further metabolic activities of the starter culture during storage (Bonczar et al., 2002). 
TABLE 3. Total phenolic content (TPC) of stirred synbiotic fermented milk fortified with fig puree.

\begin{tabular}{cc}
\hline Samples & Total Phenolic content $\mathbf{~ m g ~ g a l l i c ~ a c i d / 1 0 0 g ~}$ \\
\hline $\mathrm{C}$ & 3.94 \\
$\mathrm{~T}_{1}$ & 9.43 \\
$\mathrm{~T}_{2}$ & 20.86 \\
$\mathrm{~T}_{3}$ & 35.84 \\
Fig puree & 195.28 \\
\hline
\end{tabular}

C: Stirred fermented milk control without fig; $\mathrm{T}_{1}$ : Stirred fermented milk with $5 \%$ fig; $\mathrm{T}_{2}:$ Stirred fermented milk with $10 \%$ fig; $\mathrm{T}_{3}$ : Stirred fermented milk with $20 \%$ fig.

TABLE 4. $\mathrm{IC}_{50}$ and antiradical power (ARP) of stirred synbiotic fermented fortified with different ratios of fig puree.

\begin{tabular}{ccc}
\hline Samples & IC $_{\mathbf{5 0}}$ & ARP \\
\hline $\mathrm{C}$ & 237.79 & 0.0042 \\
$\mathrm{~T}_{1}$ & 24.46 & 0.0408 \\
$\mathrm{~T}_{2}$ & 19.58 & 0.0510 \\
$\mathrm{~T}_{3}$ & 13.89 & 0.0719 \\
Fig puree & 6.02 & 0.1659 \\
\hline
\end{tabular}

C: Stirred fermented milk control without fig; $\mathrm{T}_{1}$ : Stirred fermented milk with $5 \%$ fig; $\mathrm{T}_{2}$ : Stirred fermented milk with $10 \%$ fig; $\mathrm{T}_{3}$ : Stirred fermented milk with $20 \%$ fig.

TABLE 5. The $\mathrm{pH}$ value of stirred synbiotic fermented fortified with different concentrations of fig puree during storage period at $4 \pm 1^{\circ} \mathrm{C}$.

\begin{tabular}{cccccc}
\hline \multirow{2}{*}{ Treatments } & \multicolumn{4}{c}{ Storage period (days) } & \multirow{2}{*}{$\begin{array}{c}\text { Treatment } \\
\text { means }\end{array}$} \\
\cline { 2 - 5 } & Fresh & $\mathbf{5}$ & $\mathbf{1 0}$ & $\mathbf{1 5}$ & $5^{\mathrm{n}}$ \\
\hline $\mathbf{C}$ & $5.34^{\mathrm{a}} \pm 0.0057$ & $5.16^{\mathrm{c}} \pm 0.0057$ & $4.93^{\mathrm{e}} \pm 0.01$ & $4.64^{\mathrm{h}} \pm 0.02$ & $4.85^{\mathrm{B}}$ \\
$\mathbf{T}_{\mathbf{1}}$ & $5.25^{\mathrm{b}} \pm 0.0057$ & $4.93^{\mathrm{e}} \pm 0.0057$ & $4.75^{\mathrm{f}} \pm 0.0152$ & $4.49^{\mathrm{i}} \pm 0.0115$ & $4.63^{\mathrm{C}}$ \\
$\mathbf{T}_{\mathbf{2}}$ & $5.02^{\mathrm{d}} \pm 0.1527$ & $4.7^{\mathrm{g}} \pm 0.0057$ & $4.5^{\mathrm{i}} \pm 0.02$ & $4.3^{\mathrm{k}} \pm 0.0173$ & $4.43^{\mathrm{D}}$ \\
$\mathbf{T}_{\mathbf{3}}$ & $4.77^{\mathrm{f}} \pm 0.01$ & $4.42^{\mathrm{j}} \pm 0.0057$ & $4.32^{\mathrm{k}} \pm 0.0264$ & $4.24^{\mathrm{l}} \pm 0.02$ & - \\
Period means & $5.1^{\mathrm{A}}$ & $4.8^{\mathrm{B}}$ & $4.6^{\mathrm{C}}$ & $4.4^{\mathrm{D}}$ & - \\
\hline
\end{tabular}

C: Stirred fermented milk control without fig; $\mathrm{T}_{1}$ : Stirred fermented milk with $5 \%$ fig; $\mathrm{T}_{2}$ : Stirred fermented milk with $10 \%$ fig; $\mathrm{T}_{3}$ : Stirred fermented milk with $20 \%$ fig.

Values with different superscript letters are significantly different $(\mathrm{P} \square 0.05)$.

TABLE 6. Titratable acidity (as lactic acid \%) of stirred synbiotic fermented milk fortified with different concentrations of fig puree during storage period at $4 \pm 1^{\circ} \mathrm{C}$.

\begin{tabular}{|c|c|c|c|c|c|}
\hline \multirow{2}{*}{ Treatments } & \multicolumn{4}{|c|}{ storage period (days) } & \multirow{2}{*}{$\begin{array}{c}\text { Treatment } \\
\text { means }\end{array}$} \\
\hline & Fresh & 5 & 10 & 15 & \\
\hline $\mathrm{C}$ & $0.48^{\mathrm{I}} \pm 0.01$ & $0.54^{\mathrm{g}} \pm 0.0057$ & $0.59^{\mathrm{f}} \pm 0.0057$ & $0.68^{\mathrm{d}} \pm 0.010$ & $0.57^{\mathrm{D}}$ \\
\hline T1 & $0.52^{\mathrm{h}} \pm 0.0057$ & $0.58^{f} \pm 0.010$ & $0.63^{\mathrm{e}} \pm 0.010$ & $0.72^{\mathrm{c}} \pm 0.0057$ & $0.61^{\mathrm{C}}$ \\
\hline $\mathbf{T 2}$ & $0.53^{\mathrm{g}} \pm 0.0057$ & $0.63^{\mathrm{e}} \pm 0.010$ & $0.70^{\mathrm{c}} \pm 0.0057$ & $0.80^{\mathrm{b}} \pm 0.0057$ & $0.67^{\mathrm{B}}$ \\
\hline T3 & $0.63^{\mathrm{e}} \pm 0.0152$ & $0.71^{\mathrm{c}} \pm 0.0057$ & $0.81^{\mathrm{b}} \pm 0.0057$ & $0.91^{\mathrm{a}} \pm 0.0057$ & $0.77^{\mathrm{A}}$ \\
\hline Period means & $0.54^{\mathrm{D}}$ & $0.61^{\mathrm{C}}$ & $0.68^{\mathrm{B}}$ & $0.78^{\mathrm{A}}$ & - \\
\hline
\end{tabular}

C: Stirred fermented milk control without fig; $\mathrm{T}_{1}$ : Stirred fermented milk with $5 \%$ fig; $\mathrm{T}_{2}$ : Stirred fermented milk with $10 \%$ fig; $\mathrm{T}_{3}$ : Stirred fermented milk with $20 \%$ fig.

A, B, and D: means within the treatments and storage period effect having different capital superscripts are significantly different $(\mathrm{P} \leq 0.05)$.

$\mathrm{a}, \mathrm{b}$, andd: means within the interaction having different small superscripts are significantly different $(\mathrm{P} \square 0.05)$

Egypt. J. Food. 47, No.2 (2019) 


\section{Kinetic parameters of acidification}

The results of the effect of adding fig puree in different concentrations in fermented milk on the growth kinetics of Lactobacillus acidophilus by determination of titratable acidity and $\mathrm{pH}$ can be noticed in Tables 7 and 8, we notice that once the addition of fig puree to fermented milk resulted in decreased $\mathrm{pH}$ and increased titratable acidity. The increase in the percentage of added fig increases the decrease in $\mathrm{pH}$ and increases titratable acidity. After 14 hours of fermentation there was a clear reduction in $\mathrm{pH}$ for all samples but the samples supported by fig puree were lower for $\mathrm{pH}$ and higher values of titratable acidity, Sample $\mathrm{T}_{3}$ has the lowest in $\mathrm{pH}$ and the highest value in titratable acidity and values were 5.02 and 1.25 , respectively. This is followed by samples T2 values (5.1 and 1.1) and samplesT1 values (5.28, and 0.87$)$ for $\mathrm{pH}$ and titratable acidity respectively.

\section{Microbiological analyses}

The results of microbiological analysis are recorded in Table 9. The L. acidophilus counts in the samples of stirred fermented milk fortified by fig puree (T3, T2 and T1respectively) were significantly $(p<0.05)$ higher in comparing with that of control samples over the time of storage. The maximum counts of $L$. acidophilus at fresh and after 15 days of storage at $4 \pm 1{ }^{\circ} \mathrm{C}$ were 11.43 and $10.74 \mathrm{log} \mathrm{cfu} / \mathrm{ml}$ for samples T3. Which are followed by the count of T2, T1 and control, these results within the established standard for probiotic foods (Nazzaro et al., 2012). This means that the addition of fig puree to stirred fermented milk increases the activity of L. acidophilus and is an excellent substrate for the growth of them. During the storage period the counts of $L$. acidophilus were significantly decreased $(\mathrm{p}<0.05)$. After the end of storage period at $4 \pm 1{ }^{\circ} \mathrm{C}$ the lowest count of L. acidophilus are $8.97 \mathrm{log} \mathrm{cfu} / \mathrm{ml}$ for control samples, then followed by samples of T1, T2 and $\mathrm{T} 3$ respectively. In the light of these results, we can conclude that fig adding to fermented milk enhances the growth of L. acidophilus and consequently increases the probiotics activity of the fermented milk (Thakkar and Preetha, 2016).
All of Staphylococcus aureus, coliforms group, molds and yeasts were not detected in control and all treatments of stirred synbiotic fermented milk whether when fresh or during storage period. This might be due to the efficient heat treatment of milk which inhibits the vegetative cells, also the sanitation and hygienic conditions during the manufacture process of the product.

\section{Sensory evaluation}

Results shown in Table 10 represented the changes of the sensory evaluation of synbiotic stirred fermented milk with fig puree, statistically analyzed found that, the highest rank score was found for T2 samples in terms of color and flavor, while the lowest rank for color and flavor were seenin case of samples T3 and control. However, the highest rank of appearance and consistency were seen for $\mathrm{T} 1$ samples while the lowest rank of appearance and consistency were seen for control and T3 samples. The overall acceptability was highly acceptable in samples of T1 and T2 compared with control. However, the scores of organoleptic properties were variation in all treatments during storage at $4 \pm 1{ }^{\circ} \mathrm{C}$ till the end. According to Teshome et al., (2017) Addition of the fruit to yoghurt with optimal level improved sensory attributes and physic-chemical properties of yoghurt.

\section{Conclusion}

In conclusion, fortified fermented milk with fig puree in different levels may increase nutritional value and the function properties of stirred fermented milk. It could be used to increase the dietary fibers, polyphenols, antioxidant potential, minerals and improving the growth of L. acidophilus in stirred fermented milk. This product makes combination between the probiotic properties of stirred yogurt and prebiotic properties of fruit. 

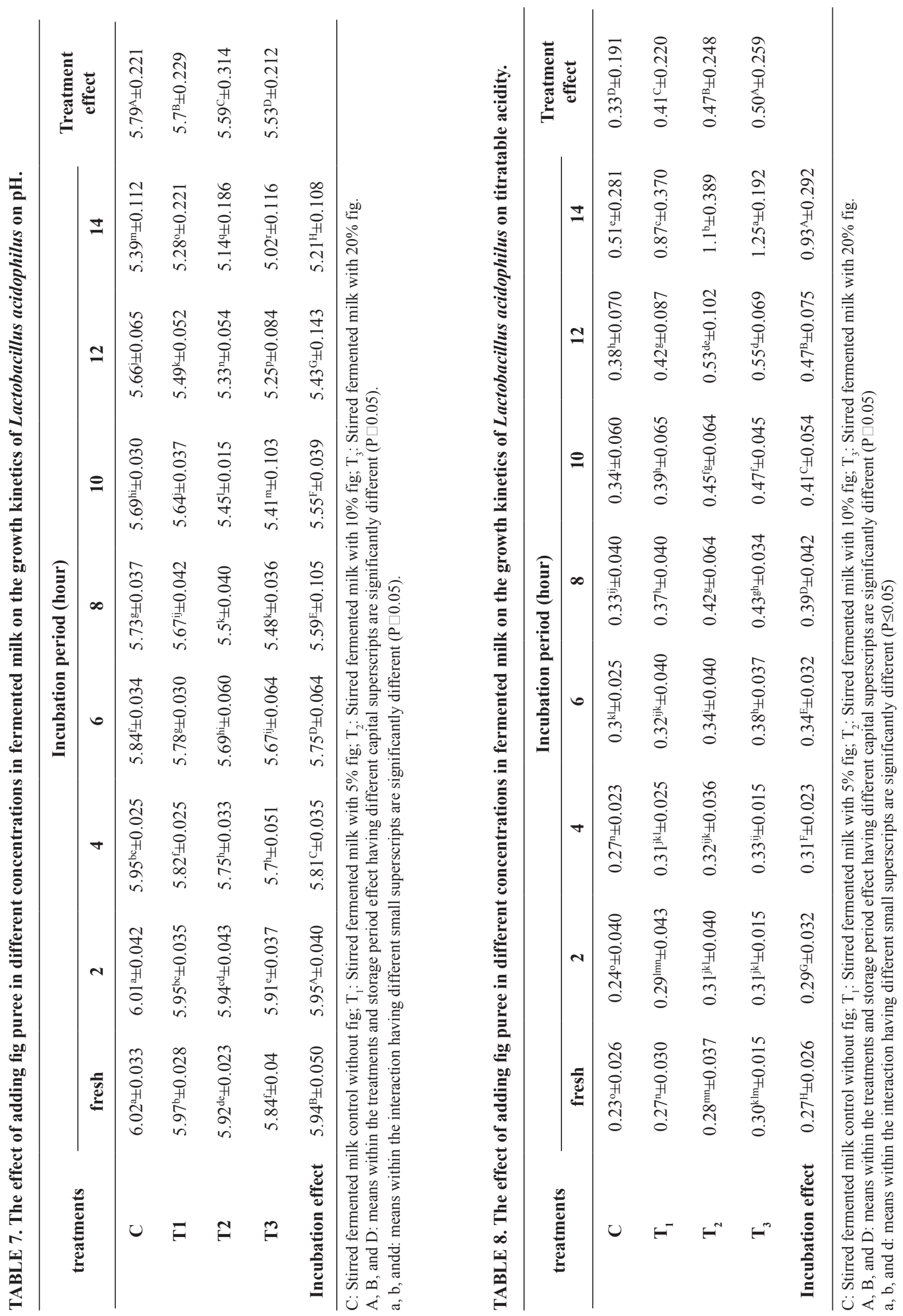

Egypt. J. Food. 47, No.2 (2019) 

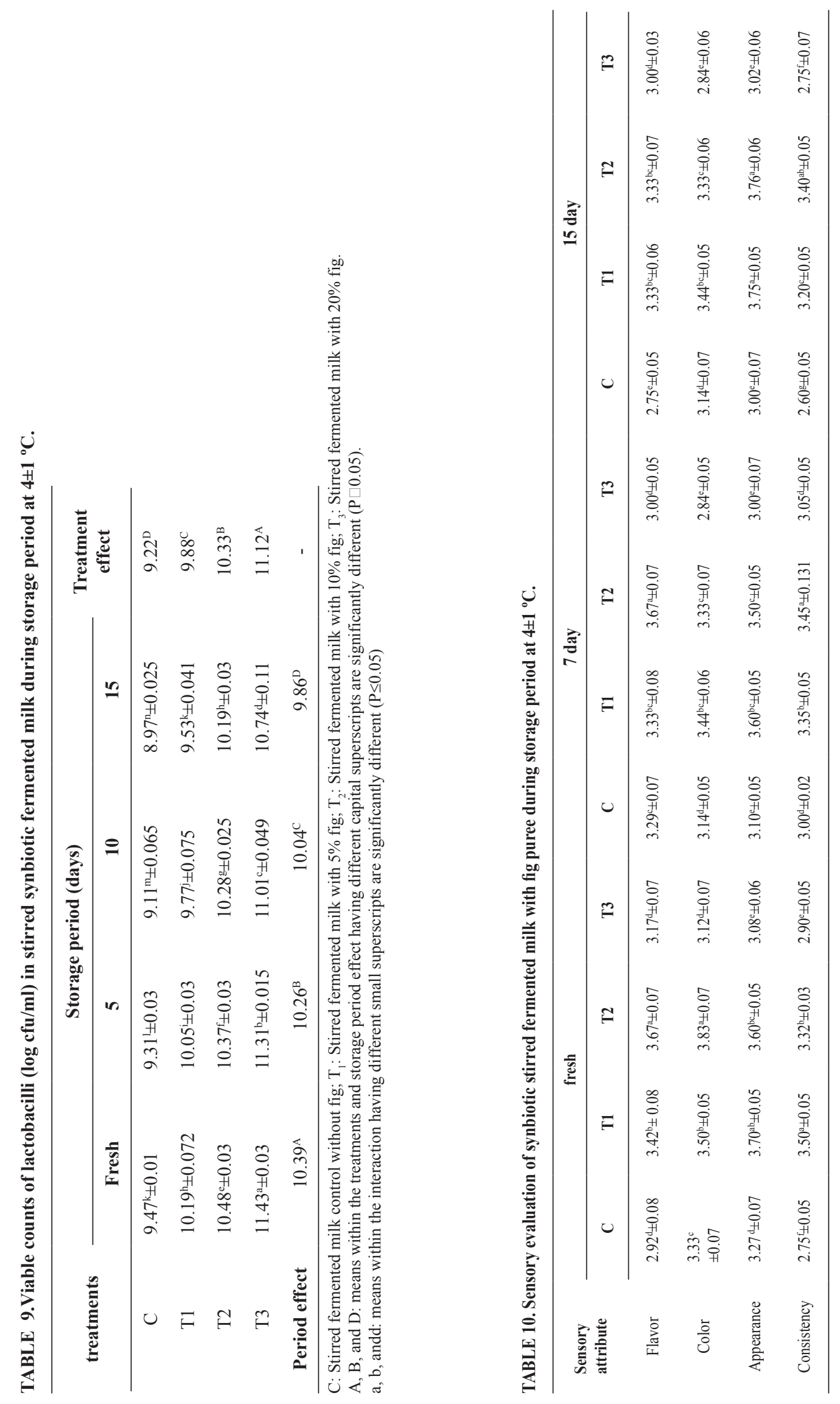

Egypt. J. Food. 47, No.2 (2019) 


\section{Reference}

Akowuah, G.A., Ismail, Z., Norhayati, I. and Sadikun, A. (2005) The effects of different extraction solvents of varying polarities of polyphenols of Orthosiphonstamineus and evaluation of the free radical-scavenging activity. Food Chemistry, 93, 311-317.

Ali, M.Y., M.A. Islam, M.J. Alam and M.N. Islam, (2002) Quality of Yoghurt (Dahi) made in Laboratory and Available in the Market of My mensingh Town in Bangladesh. Pak. J. Biol. Sci., 5, 343-345.

AOAC (2012) Official Methods of Analysis of the Association of Analytical Chemists.18th Ed., Washington, D.C., USA.

APHA (1992) American Publish Health Association Compendium of Methods for the Microbiological Examination of Foods. Washington D.C, USA.

Ashwani K. and Dinesh K. (2015). Development of antioxidant rich fruit supplemented probiotic yogurts using free and microencapsulated Lactobacillus rhamnosus culture. J. Food Sci. Technol. ISSN 0022-1155.

Bachirbey M., Louaileche H. and Zemouri S. (2013) Optimization of phenolic compound recovery and antioxidant activity of light and dark dried fig (Ficus carica L.) varieties. Food Sci. Biotechnol. 22,1613-1619

Bakirci, K. and Kavaz, A. (2008) An investigation of some properties of banana yoghurts made with commercial ABT-2 starter culture during storage. Int. J. Dairy Technology, 6 (1), 270-276.

Bonczar, G, M. W. andSiuta, A. (2002) The effects of certain factors on the properties of yogurt made from ewe's milk. Food Chem. 79, 85-91.

Brand-Williams W., Cuvelier M.E. and Berset C. (1995) Use of a free radical method to evaluate antioxidant activity. Lebensm.Wiss.Tech-No. I, 25.

Capanoglu E. ( 2014) Investigating the antioxidant potential of Turkish dried fruits. Int. J. Food Prop. 17, 690-702.

Celik, S., I. Bakirci and Sat, I.G. (2006) Physicochemical and organoleptic properties of yoghurt with Cornelian cherry marmalade. Int. J. Food Properties, 9, 401-408.

DelloStaffolo, M., Sato, A., \& Cunha, R. (2017) Utilization of plant dietary fibers to reinforce low- calorie dairy dessert structure. Food and Bioprocess Technology, 10 (5), 914-925

Duncan, D. B. (1955) Multiple range and multiple Ftest. Biometrics, 11,1-42.

Erman E., Özer K., Oktay Y. and Merve A. (2011) Effect of phenolic compounds on characteristics of strained yoghurts produced from sheep milk. African Journal of Agricultural Research, 6 (23), 5351-5359.

Granato, D.; Nunes, D.S.; Barba, F.J. (2017) An integrated strategy between food chemistry, biology, nutrition, pharmacology, and statistics in the development of functional foods: A proposal. Trends Food Sci. Technol. 62, 13-22.

Hanan A. J. (2018). Evaluation of Physio-Chemical and Sensory Properties of Yogurt Prepared with Date Pits Powder. Current Science International. 7 (1), $1-9$.

Hayat, A. C. and Salem, B. (2011) Total contents of major minerals in the nature yoghurt and in the yoghurts with the date powder of three dry varieties. American J. of and Nutrition, 1 (2), 74-78.

Helmyati, S.; Rahayu, E. S.; IstitiKandarina, B.J. and Juffrie, M. (2015) Sensory evaluation comparison of formulated fermented milk and commercial fermented milk: A new Formulated fermented milk as food supplement for Iron-deficiency Anemia elimination program. Int. J. Curr. Microbiol. App. Sci. 4 (7), 657-665.

Hossain,N. FakruddinMd and NurulI.(2012).Quality comparison and acceptability of yoghurtwith different fruit juices. J. Food Process and Technol. $3,1-5$.

Jeong MR, Kim HY, Cha JD. (2009) Antimicrobial Activity of Methanol Extract from Ficuscarica Leaves Against Oral Bacteria. Journal of Bacteriology and Virology; 39 (2), 97-102.

Lee W.J. and J.A. Lucey (2010). Formation and Physical Properties of Yoghurt. Asian-Australian J. An. Sci. 23 (9), 1127 - 1130.

McCanceetWiddowson,(1993)Thecompositionoffoods $\left(5^{\text {th }}\right.$ revised and extended ed.). Cambridge, UK. The Royal Society ofChemistry and Ministry ofAgriculture, Fisheries and Food.

Mostapha B. B. and Hayette L. (2015) A comparative study of phytochemical profile and in vitro antioxidant activities of dark and light dried fig (Ficus carica L.) varieties. The Journal of

Egypt. J. Food. 47, No.2 (2019) 
Phytopharmacology, 4 (1), $41-48$.

Nazzaro, F., Fratianni, F., Nicolaus, B., Poli, A.and Orlando, P. (2012) The prebiotic source influences the growth, biochemical features and survival under simulated gastrointestinal conditions of the probiotic Lactobacillus acidophilus. Anaerobe, 18, $280-285$.

Neha S., Sanchi M., Gouri S., and Rajinder K. G. (2014).Estimation of nutritional, phytochemical, antioxidant and antibacterial activity of dried fig (Ficus carica). Journal of Pharmacognosy and Phytochemistry, 3 (2), 158-165.

O'Connell, J.E. and Fox, P.F. (2001) Significance and applications of phenolic compounds in the production and quality of milk and dairy products: A review. Int. Dairy J., 11, 103-120.

Raikos, V., Ni, H., Hayes, H., and Ranawana, V. (2019) Antioxidant Properties of a Yogurt Beverage Enriched with Salal (Gaultheria shallon) Berries and Blackcurrant (Ribes nigrum) Pomace during Cold Storage. Beverages, 5 (2) beverages50100022; doi: 10.3390/beverages5010002.

Rice-Evans, C.A, Miller, N.J and Paganga, G. (1997) Antioxidant properties of phenolic compounds. Trends in Plant Science, 2, 152-159.

Samah M. I., Azza M. F., Yaser M. E. and Safaa T. G. (2014) Functional and Nutritional Properties of Stirred Yoghurt Supplemented with Silymarin and its Impact on Chronic Hepatic Damage. World Journal of Dairy \& Food Sciences, 9 (1), 36-50.

Sanders, M.E. (2007). Probiotics, Strains Matter. Functional Foods \& Nutraceuticals Magazine. Food Science, p. 36-41.

Sendra, E., Kuri,V. Fernández-López,J. Sayas-Barberá, E. Navarro,C. and Pérez-Alvarez, J. A. (2010) Viscoelastic properties of orange fiber enriched yogurt as a function of fiber dose, size and thermal treatment. LWT - Food Science and Technology, 43 (4), 708-714.

Shabboo, A. and Ahmad, S. H. (2015) Green tea yogurt: major phenolic compounds and microbial growth. J. Food Sci. Technol. 52 (7), 4652-4660.

Singleton, V.L. and Rossi, J.A., (1965) Colorimetry of phosphomolybdicphosphotungstic acid reagents. American Journal of Enology and Viticulture, 16, 144-158.

Soni, N., Mehta, S., Satpathy, G. and Gupta, R.K., (2014) Estimation of nutritional, phytochemical, antioxidant and antibacterial activity of dried fig (Ficus carica). Journal of Pharmacognosy and Phytochemistry, 3 (2) 158-165.

Soufi, O., Romero, C., Louaileche, H. (2014) Orthodiphenol profile and antioxidantactivity of Algerian black olive cultivars: Effect of dry salting process. Food Chem.157, 504-510.

SPSS.(1999) Statistical Package for Social Sciences. SPSS Inc., Chicago, IL, USA.

Tamime, A.Y. and Robisons, R.K. (2007) Chapter 1 Historical Background. In Tamime and Robinson's Yogurt: Science and Technology, 3rd ed., Woodhead Publishing: Cambridge, UK. pp. 1-10.

Teshome, G., Keba, A., Assefa, Z.,Agza, B., and Kassa, F., (2017) Development of Fruit Flavored Yoghurt with Mango (Mangifera indica L.) and Papaya (Carica papaya L.) Fruits Juices. Food Science and Quality Managem. Vol.67. www.iiste.org SN 22246088 (Paper) ISSN 2225-0557 (Online)

Thakkar, U. and Preetha, R. (2016) Evaluation of Fig Powder as Prebiotic and its Utilization for Development of Synbiotic Microcapsules. Biosciences Biotechnology Research Asia. 13 (2), 1223-1229.

Tomic, N., Dojnov, B., Miocinovic, J., Tomasevic, I., Smigic, N., Djekic, I.,\&Vujcic, Z. (2017) Enrichment of yoghurt with insoluble dietary fiber from triticale.A sensory perspective. $L W T$ - Food Science and Technology, 80, 59-66.

Velázquez Vásquez, C., Villa Rojas, M.G., Alvarez Ramírez, C., Chávez-Servín, J.L., García-Gasca, T., Ferriz Martínez, R.A., Garcia, O.P., Rosado, J.L., López-Sabater, C.M. and Castellote, A.I. (2015) Total phenolic compounds in milk from different species. Design of an extraction technique for quantification using the Foline-Ciocalteu method. Food Chem. 176, 480-486.

Vijaya Kumar Reddy C., Sreeramulu D. and Raghunath M.(2010) Antioxidant activity of fresh and dry fruits commonly consumed in India. Food Res. Int. 43 (1), 285-288.

Vinson, J.A. (1999). The functional food properties of figs. Cereal Foods World. 44 (2), 82-87.

ZamberlinŠ.,Neven A., Jasmina H., Dubravka S. (2012) Mineral elements in milk and dairy products. Mljekarstvo, 62 (2), 111-125. 


\title{
انتاج وتقييم اللبن المتخمر المقلب الصحي المدعم بفاكهة التين \\ سماح عبد التواب و وردة عبيد

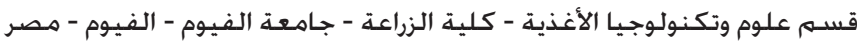

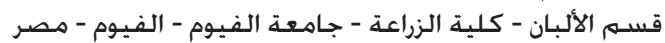

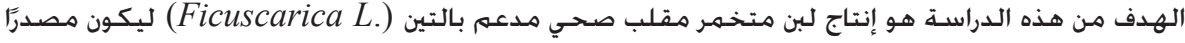

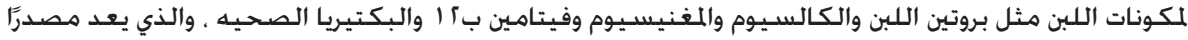

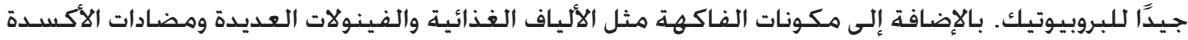

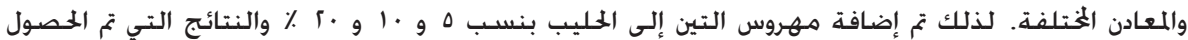

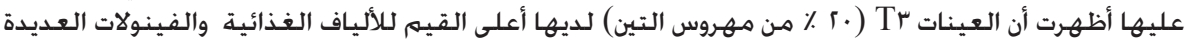

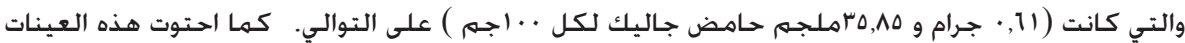

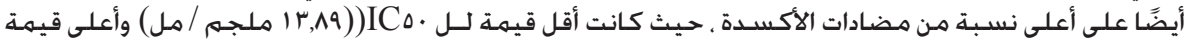

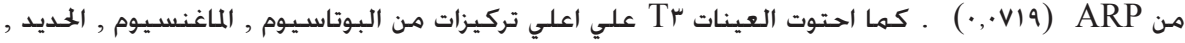

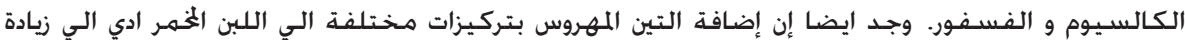

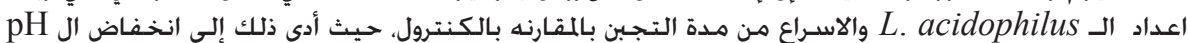

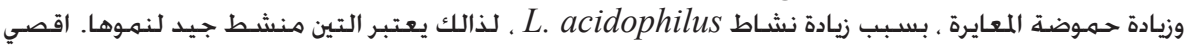

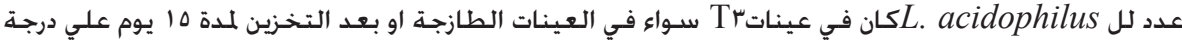
$.1 \pm \varepsilon \rho^{0}$

اظهر التقيه الحسي لعينات اللبن الخمـمر والمقلب المدعومة بالتين انها كانت اكثر قبولا حسيا مقارنة بالعينات التي لهم يضاف لهها تين.
\end{abstract}

